\title{
PEMANFAATAN COFFEE HUSK DENGAN PENAMBAHAN KULIT BUAH DURIAN SEBAGAI COFFEE HUSK LEATHER
}

\author{
(Utilization of Coffee Husk with Addition of Durian Fruit Peel as Coffee \\ Husk Leather)
}

\author{
Evan Keizha ${ }^{a^{*}}$, Sutarjo Surjoseputro ${ }^{a}$, Erni Setijawatya \\ aFakultas Teknologi Pertanian-Universitas Katolik Widya Mandala Surabaya, Indonesia \\ ${ }^{*}$ Penulis korespondensi \\ Email: evankeizha@gmail,com
}

\begin{abstract}
Coffee is one of commodities which has very high production level in Indonesia, and puts Indonesia as the fourth largest coffee producer in the World. High production of coffee will cause an increasement of coffee waste processing. One of the waste is the coffee husk. Utilization of coffee husk in food industry is still very limited so it creates opportunities to be used as fruit leather. Fruit leather is one of food product derived from dried fruit pulp until 10-15\% moisture content. Leather with $100 \%$ of coffee husk cannot made from a chewy texture due to the unstable gel formation, because coffee husk contains only $1.6 \%$ of pectin. So, to improve the texture of leather, pectin will be added from durian fruit peel. Durian fruit peel has $9.16 \%$ of Pectin content. In this Research, I'm using Non-Factorial Randomized Block Design (RBD) that consist of one factor which is addition of durian fruit pulp with concentrations of $10 \%, 20 \%, 30 \%$, $40 \%, 50 \%$, and $60 \%$ with four times repetition. The parameter tested including physiochemical properties such as water content, water activity, texture, $\mathrm{pH}$,color and organoleptic properties (preference for texture, colour, and flavor). The difference in the concentration of the addition of durian fruit peel which is increasing results in an increase in $\mathrm{pH}(3,39-3,49)$, increase in water content $(9,08-13,45)$, decrease in water activity $(0,60-0,56)$, increase in gumminess values $(31,13-736,61)$. The range of lightness values $\left(25,88\right.$ - 31,59), chroma $(2,49-8,98)$, and hue $\left(179,89^{\circ}-12,95^{\circ}\right)$. The best treatment chosen based on organoleptic test with spider web method is $40 \%$ durian fruit peel addition.
\end{abstract}

Keywords: Coffee husk, fruit leather, durian peel.

\begin{abstract}
ABSTRAK
Kopi merupakan salah satu komoditi yang tingkat produksinya di Indonesia sangat tinggi, sehingga menempatkan Indonesia sebagai produsen kopi terbesar nomor empat di dunia. Produksi kopi yang tinggi akan menyebabkan limbah hasil samping pengolahan kopi juga meningkat. Salah satu limbah yang dihasilkan adalah coffee husk. Pemanfaatan Coffee husk dalam bidang pangan masih sangat terbatas sehingga memberikan peluang untuk dimanfaatkan menjadi produk fruit leather. Fruit leather merupakan salah satu jenis produk olahan pangan yang berasal dari bubur daging buah yang dikeringkan hingga kadar air berkisar 10-15\%. Leather dengan bahan 100\% coffee husk tidak dapat membentuk tekstur yang kenyal karena pembentukan gel yang tidak kokoh akibat kandungan pektin pada coffee husk yang hanya sebesar $1.6 \%$ sehingga untuk memperbaiki tekstur leather tersebut ditambahkan pektin dari bubur kulit buah durian. Kulit buah durian memiliki kandungan pektin sebesar 9.16\%. Rancangan penelitian yang digunakan adalah Rancangan Acak Kelompok (RAK) Non Faktorial yang terdiri dari satu faktor yaitu penambahan bubur kulit buah durian dengan konsentrasi (10\%, 20\%, 30\%, 40\%, 50\%, dan 60\%) dan diulang sebanyak 4 (empat) kali. Parameter yang diuji meliputi sifat fisikokimia (kadar air, tekstur, $\mathrm{pH}$, dan warna) dan sifat organoleptik (kesukaan terhadap tekstur, warna, dan rasa). Perbedaan konsentrasi penambahan bubur kulit buah durian yang semakin banyak menghasilkan peningkatan $\mathrm{pH}(3,39-3,49)$,
\end{abstract}


peningkatan kadar air $(9,08-13,45)$, penurunan aktivitas air $(0,60-0,56)$, peningkatan nilai gumminess $\left(31,13\right.$ - 736,61). Rentang nilai lightness $\left(25,88\right.$ - 31,59), chroma $(2,40-8,98)$, dan hue $\left(179,89^{\circ}\right.$ $\left.12,95^{\circ}\right)$. Perlakuan terbaik dipilih berdasarkan uji organoleptik dengan metode spider web adalah konsentrasi penambahan kulit buah durian sebesar $40 \%$.

Kata kunci: Coffee husk, fruit leather, kulit buah durian.

\section{PENDAHULUAN}

Indonesia merupakan salah satu negara produsen dan eksportir kopi terbesar di dunia. Tingginya produksi kopi di Indonesia tersebut menempatkan Indonesia sebagai produsen kopi terbesar nomor empat di dunia (Meiri et al., 2013). Banyaknya jumlah kopi yang dihasilkan di Indonesia tersebut, menyebabkan limbah hasil samping dari pengolahan kopi juga sangat tinggi. Limbah dari hasil samping pengolahan tersebut berupa daging buah secara fisik sebesar $48 \%$ yang terdiri atas $42 \%$ kulit buah dan $6 \%$ kulit biji (Zainuddin et al., 1995). Akibat banyaknya limbah kulit buah kopi tersebut, diperlukan sebuah cara untuk memanfaatkan limbah tersebut agar dapat meningkatkan efisiensi dari penggunaan buah kopi.

Limbah kulit buah kopi terdapat dua jenis yang berbeda, yaitu coffee husk dan coffee pulp. Coffee husk merupakan hasil limbah kulit kopi dari pengolahan kopi dengan metode kering (Brand, 2000). Salah satu kandungan dari coffee husk yang dapat dimanfaatkan adalah kandungan pektinnya yang sebesar $1.6 \%$ (Murthy dan Naidu, 2012). Adanya kadungan pektin dalam coffee husk tersebut mendasari pemikiran dari penelitian ini untuk memanfaatkan limbah kulit kopi jenis coffee husk menjadi fruit leather.

Berdasarkan orientasi penelitian, pembuatan fruit leather dengan menggunakan bahan 100\% bubur kulit buah kopi menghasilkan produk yang memiliki kekenyalan yang sangat rendah. Hal tersebut dikarenakan kandungan pektin dalam coffee husk yang sangat rendah sehingga tidak mencukupi untuk membentuk suatu tekstur yang kenyal pada leather. Kekurangan pektin tersebut dapat diperbaiki dengan penambahan bahan pangan lain yang mengandung pektin cukup tinggi, salah satunya adalah kulit buah durian.

Campuran antara bubur coffee husk dan kulit buah durian akan digunakan sebagai bahan pembuatan fruit leather. Konsentrasi bubur coffee husk dan bubur kulit buah durian yang digunakan akan mempengaruhi sifat fisikokimia dan organoleptik dari fruit leather yang dihasilkan. Pada penelitian ini akan dilakukan penambahan bubur kulit buah durian dengan konsentrasi 10\% (b/b); $20 \%$ (b/b); 30\% (b/b); 40\% (b/b); 50\% (b/b); dan $60 \%$ (b/b). Tujuan dari penelitian ini adalah untuk mengetahui pengaruh konsentrasi bubur kulit buah durian yang ditambahkan terhadap sifat fisikokimia dan organoleptik fruit leather yang dihasilkan.

\section{Bahan}

\section{BAHAN DAN METODE}

Bahan-bahan yang digunakan dalam penelitian ini adalah coffee husk dari varietas biji kopi Arabika Jawa (Toko Farenno Surabaya), Kulit buah durian (Aditya sus duren dan ketan duren Surabaya), Gula (Gulaku), Asam sitrat, dan air minum dalam kemasan.

\section{Alat untuk proses}

Alat yang digunakan dalam proses pengolahan fruit leather bubur coffee husk bubur kulit buah durian adalah Blender (Miyako), cabiner dryer (Memmet), tray, neraca digital (Camry), kompor gas (Rinnai), panci, pisau, sendok, mangkuk aluminium, saringan, cetakan plastik ukuran $13 \times 8 \times 1.5 \mathrm{~cm}$. 


\section{Alat untuk analisa}

Alat-alat yang digunakan untuk analisa adalah timbangan analitik (Mettler Toledo), texture analyzer (Stable Micro System TAXT Plus), pH meter, colour reader (Konika Minolia CR-10 chromameter), oven vakum (BINDER), penangas air, botol semprot, botol timbang, eksikator, gelas beker, Erlenmeyer, pipet ukur, labu ukur, pengaduk, pipet tetes, perlengkapan organoleptik, dan kuisioner.

\section{Metode penelitian}

Rancangan penelitian yang digunakan adalah Rancangan Acak Kelompok (RAK) dengan satu faktor, yaitu konsentrasi penambahan bubur kulit buah durian yang terdiri dari 6 level. Penelitian akan dilakukan pengulangan sebanyak empat kali. Formulasi pada proses pembuatan kwetiau kering beras hitam dapat dilihat pada Tabel 1.

Coffee husk akan dibuburkan
menggunakan
penamabahan air 1:10 dan kulit buah durian juga dilakukan pembuburan menggunakan blender dengan penambahan air 1:4. Bubur coffee husk kemudian ditimbang sebanyak 350 gram dan dicampur dengan bubur kulit buah durian sesuai dengan formulasi, gula $30 \%$, dan asam sitrat $1 \%$. Adonan yang didapatkan kemudian dicetak pada cetakan mika plastik dengan ukuran $13 \times 8 \times 1.5 \mathrm{~cm}$ dan dikeringkan menggunakan cabinet dryer dengan suhu $70-80^{\circ} \mathrm{C}$ selama \pm 7 jam dan didapatkan produk leather coffee husk.

\section{HASIL DAN PEMBAHASAN}

Leather coffee husk akan diuji secara fisikokimia meliputi $\mathrm{pH}$, kadar air, $\mathrm{a}_{\mathrm{w}}$, gumminess, warna dan organoleptik meliputi warna, tekstur dan rasa dengan kisaran nilai yang dapat dilihat pada Tabel 2.

\section{Organoleptik}

Pengujian organoleptik leather coffee husk menggunakan metode hedonic scale scoring dengan parameter warna, tekstur, dan rasa. Berdasarkan hasil pengujian didapatkan nilai kesukaan warna leather coffee husk dengan berbagai konsentrasi penambahan bubur kulit buah durian antara 2,84 - 4,37 (tidak suka hingga netral). Berdasarkan uji ANOVA didapatkan hasil bahwa perbedaan penambahan bubur kulit buah durian akan menyebabkan adanya perbedaan yang nyata terhadap warna leather dan dilanjutkan uji DMRT. erdasarkan hasil pengujian, panelis lebih menyukai penambahan bubur kulit buah durian sebanyak $60 \%$ yang menunjukkan nilai rata-rata sebesar 4.37., namun perlakuan tersebut tidak berbeda nyata dengan perlakuan penambahan kulit buah durian sebesar $40 \%$ dan $50 \%$. Nilai kesukaan warna memiliki perbedaan dalam penilaiannya karena dengan penamabahan bubut kulit buah durian yang berwarna putih akan menyebabkan warna dari leather akan semakin terang.

Nilai kesukaan terhadap tekstur leather coffee husk berkisar antara 3,3 - 4,2 (agak tidak suka hingga netral). Pengujian tersebut dianalisa dengan ANOVA dan mendapatkan hasil bahwa perbedaan konsentrasi penambahan bubur kulit buah durian akan menyebabkan adanya perbedaan yang nyata terhadap warna leather dan dilanjutkan uji DMRT. Berdasarkan hasil pengujian, panelis lebih menyukai penambahan bubur kulit buah durian sebanyak $40 \%$ yang menunjukkan nilai rerata sebesar 4,2 , namun perlakuan tersebut tidak berbeda nyata dengan perlakuan penamabahan bubur kulit buah durian 50\%. Nilai kesukaan tekstur meningkat hingga perlakuan penambahan bubur kulit buah durian sebesar $40 \%$ karena adanya peningkatan pektin yang akan berpengaruh pada kekenyalan dari leather.

Nilai kesukaan terhadap rasa leather coffee husk berkisar antara 3,6 - 4,3 (agak tidak suka hingga netral). Pengujian tersebut dianalisa dengan ANOVA dan mendapatkan hasil bahwa perbedaan konsentrasi penambahan bubur kulit buah durian akan menyebabkan adanya 
Tabel 1. Formulasi Bubur Coffee Husk dan Kulit Buah Durian

\begin{tabular}{lcccccc}
\hline \multirow{2}{*}{ Bahan } & \multicolumn{7}{c}{ Komposisi } \\
\cline { 2 - 7 } & $\mathrm{D}_{1}$ & $\mathrm{D}_{2}$ & $\mathrm{D}_{3}$ & $\mathrm{D}_{4}$ & $\mathrm{D}_{5}$ & $\mathrm{D}_{6}$ \\
\hline Bubur coffee husk $(\mathrm{g})$ & 350 & 350 & 350 & 350 & 350 & 350 \\
Bubur Kulit buah durian & 35 & 70 & 105 & 140 & 175 & 210 \\
Total & 385 & 420 & 455 & 490 & 525 & 560 \\
\hline
\end{tabular}

Tabel 2. Hasil Pengujian Sifat Fisikokimia

\begin{tabular}{|c|c|c|c|c|c|c|}
\hline \multirow{2}{*}{ Parameter } & \multicolumn{6}{|c|}{ Perlakuan } \\
\hline & $10 \%$ & $20 \%$ & $30 \%$ & $40 \%$ & $50 \%$ & $60 \%$ \\
\hline $\mathrm{pH}$ & $3,39^{a}$ & $3,42^{b}$ & $3,44^{c}$ & $3,45^{\mathrm{cd}}$ & $3,46^{d}$ & $3,40^{\mathrm{e}}$ \\
\hline Kadar air (\%) & $9,08^{a}$ & $9,10^{\mathrm{a}}$ & $10,60^{\mathrm{ab}}$ & $11,59^{a b}$ & $12,52^{b}$ & $13,45^{\mathrm{c}}$ \\
\hline$a_{w}$ & $0.595^{\mathrm{a}}$ & $0.593^{b}$ & $0.585^{c}$ & $0.581^{\mathrm{cd}}$ & $0.564^{d}$ & $0.557^{e}$ \\
\hline Gumminess & $31,125^{a}$ & $50,172^{\mathrm{a}}$ & $276,279^{b}$ & $448,571^{c}$ & $533,598^{c}$ & $736,606^{d}$ \\
\hline \multicolumn{7}{|l|}{ Warna } \\
\hline Lightness & 25,88 & 26,54 & 26,90 & 27,58 & 29,02 & 31,59 \\
\hline Redness $\left(\mathrm{a}^{*}\right)$ & 2,41 & 3,75 & 4,42 & 5,48 & 7,57 & 8,75 \\
\hline Yellowness $\left(\mathrm{b}^{\star}\right)$ & $-0,01$ & 0,23 & 0,49 & 0,78 & 1,44 & 2,02 \\
\hline Chroma & 2,40 & 3,76 & 4,44 & 5,54 & 7,71 & 8,98 \\
\hline Hue & 359,45 & 3,58 & 6,34 & 8,15 & 10,72 & 12,95 \\
\hline
\end{tabular}

Keterangan: Notasi huruf yang berbeda menunjukkan ada beda nyata pada $\alpha=5 \%$

perbedaan yang nyata terhadap warna leather dan dilanjutkan uji DMRT. Berdasarkan hasil pengujian, panelis lebih menyukai penambahan bubur kulit buah durian sebanyak $40 \%$ yang menunjukkan nilai rerata sebesar 4,3 .

\section{Perlakuan Terbaik}

Hasil uji organoleptik akan digunakan untuk menentukkan konsentrasi terbaik dengan metode spider web. Berdasarkan hasil perhitungan dinyatakan bahwa konsentrasi 40\% penambahan bubur kulit buah durian merupakan perlakuan terbaik.

\section{KESIMPULAN}

Perbedaan konsentrasi penambahan bubur kulit buah durian berpengaruh nyata terhadap sifat fisikokimia leather coffee husk meliputi $\mathrm{pH}$, kadar air, $a_{w}$, gumminess, dan warna serta uji organoleptik dengan kisaran nilai $\mathrm{pH}(3,39-3,49)$, kadar air $(9,08 \%-13,45 \%), a_{w}(0,60-0,56)$, dan gumminess $(31,13-736,61)$. Rentang nilai lightness $(25,88-31,59)$, hue $\left(359,45^{\circ}\right.$ $\left.12,95^{\circ}\right)$, dan chroma $(2,40-8,98)$ untuk warna leather coffee husk, serta perlakuan terbaiknya adalah konsentrasi penamabahan bubur kulit buah durian sebesar $40 \%$.
UCAPAN TERIMA KASIH

Ucapan terima kasih saya sampaikan kepada semua laboran Fakultas Teknologi Pertanian Universitas Katolik Widya Mandala Surabaya yang telah memberikan bantuan teknis di dalam penulisan ini.

\section{DAFTAR PUSTAKA}

Brand, D., A. Pandey, C.R. Soccol, P. Nigam, R. Mohan, S. Roussos. 2000. Biotechnological Potential of Coffee Pulp and Coffee Husk for Bioprocess, Biochemical Engineering Journal. 6: 135-162.

Meiri, A., R. Nurmalina, A. Rifin. 2013. Analisis Perdagangan Kopi Indonesia di Pasar Internasional, Buletin Risti. 4(1): 39-46.

Murthy, P. S. dan M. M. Naidu. 2012. Sustainable Management of Coffee Industri by products and value addition-A review. Resources, Conservation, and Recycling. 66: 45-58.

Zainuddin, D., Sutikno, T. Haryadi dan Hernomoadi. 1995. Kecernaan dan Fermentasi Limbah Kakao serta Pemanfaatannya pada Ternak Ayam. Kumpulan Hasil-Hasil Penelitian APBN TA 94/95. Balai Penelitian Ternak, Ciawi, Bogor. 